\title{
Giving Consumers of British Public Services More Choice: What can be Learned from Recent History?
}

\author{
PERRI 6 \\ Director, Policy Programme, Institute for Applied Health and Social Policy, 5th Floor, \\ Franklin Wilkins Building, 150 Stamford Street, London SE1 9NN
}

\begin{abstract}
British Prime Minister Tony Blair announced in the autumn of 2001 that he wanted to extend individual consumer choice in the public services (Blair, 2001). What do we know from recent experience about the conditions under which such policies can be sustained? In this article, the experience of individual consumer choice over the last ten, and in some cases, fifteen years, is compared across nine fields of British public services. The article identifies the policy goals for introducing choice, considers how far they were typically achieved, and identifies problems and unintended side-effects, including distributional problems, inefficiencies and one type of political risk. This provisional evaluation is based on a widely ranging review of literature spanning several disciplines. The principal products of the argument are two detailed tables, setting out, respectively, the degree to which the goals seem to have been achieved for each choice programme, as far as the available literature can tell us, and how far distributional, efficiency and political risk problems have dogged consumer choice in each field. In the discussion section, trends and variations are summarised. Finally, some lessons are drawn from the comparisons, for policy makers who may be considering the further extension of consumer choice in public services.
\end{abstract}

\section{Introduction}

In a speech on 16 October 2001 on public service reform billed as a major statement, British Prime Minister Tony Blair declared that giving consumers of public services more choice, at least between providers in the event that an incumbent provider is failing, should be a central principle for reform over the next few years. The main concrete initiative announced so far has been additional choice over dates and times of appointments for elective surgery or of provider for those who have been kept waiting for longer than the target (Milburn, 2002; Secretary of State for Health, 2002: Chapter 10; see also http://www.doh.gov.uk/nhsplanbookingsystems), but there have also been suggestions from ministers of more choice of individual hospital consultant also for elective surgery. At the time of writing, it is not clear just what other initiatives 
might be announced. An Office of Public Services Reform pamphlet (2002) hinted at few new initiatives other than choice for drivers between congestion-charged routes and longer, non-charged ones.

If there is to be a significant extension of individual consumer choice schemes in public services, it will be important that their design reflects learning from the experience of choice in the last decade or more. There is a need for comparative analysis of that experience between different fields of public service. For, while many factors that explain the consequences of introducing or extending individual choice may be specific to particular services, comparative analysis is the most effective method for distinguishing those service-specific factors from ones that are more generic. Moreover, policy debate about choice is often conducted by reference to general claims about its benefits, difficulties or unwanted consequences, or to hypothesised inferences from one field to another, for the evaluation of which comparative analysis is well suited. Comparison should also illuminate the range of possible designs for choice schemes, and may suggest important clues about the reasons for their being selected, and, we might hope, at least some hypotheses for further exploration about the relationship between goals, designs and consequences. Finally, by revealing both what has been learned about choice and how it has been learned in the best studied fields, comparative analysis of findings from existing literature can identify what we might usefully want to learn from future research about the less well-studied fields and about new initiatives.

This article offers a preliminary and provisional comparison based on a review of literature on the experience of individual consumer choice since the late 1980 s in nine fields of British public services, examining what can be said about the extent to which the likely goals were achieved, and of other problems encountered. It is based on a review of the main available texts, including books and peer reviewed articles published in English mainly since about 1990 in the disciplines of social policy and administration, health policy, education policy, and public administration. Initially, definitions are given of some key terms used in the article and the scope of the analysis is presented, with definitions of the nature of choice and the types of goals. In the first substantive section, the article considers how far, according to the available literature, the goals for consumer choice in each of these fields has been achieved. In the next section, key problems experienced are identified and the nine fields compared in respect of five types of problems - polarisation, segregationist preferences, adverse selection, disproportionate transaction costs and political risks. The key products of the argument, then, are two detailed tables setting out findings on each of these issues. The concluding section draws together some lessons and implications of the review, for policy makers who may be considering the design of new programmes of reform to extend consumer choice in these areas. 


\section{Scope and definitions}

In this section, definitions are given for some of the key terms used in this article, and the scope of the analysis is set out, identifying the nine schemes of individual consumer choice to be examined in the literature review.

By 'consumer choice scheme', in this article, I mean a set of institutionalised arrangements that provide opportunities to make decisions expressing preferences between a defined menu of options (cf. Dowding, 1992: 303) in relation to services in which the state takes a financial or regulatory policy interest (6, 1998).

The present article is concerned exclusively with individual choice and neither with collective voice (for example, consultation) nor collective choice (for example, purchase of service contracting). However, it should be noted that individual 'choice' in the context of the public typically means the right to make an application for a particular provider or package of service or whatever; only in one of the cases studied in this article did consumers have the power to make a binding decision, for, in that case, they were given a cash budget to spend in the private sector (Direct Payments).

At least in principle, a consumer might be given a choice over the content of a service (specification of inputs or outputs), its level (quantity, perhaps subject to a charge above a certain threshold), the identity of a gatekeeper (case manager, commissioner, even, in one of their roles a GP), or a provider, or the manner of access (face-to-face, by telephone or over the web; choice of time and date of appointment). Some schemes provide these choices quite generally; others offer choice only when a commissioner or provider has defaulted in some respect, as in the newly announced NHS scheme to allow elective surgery patients the right to choose another or an overseas provider in the event of excessive delay (Secretary of State for Health, 2002).

I shall use the word 'voucher scheme' to mean any scheme where (a) the government provides a sum of taxpayers' money to purchase a defined service at a rate for a defined category of individual, (b) consumers may exercise some choice over the provider or gatekeeper or at least between units of service with different characteristics offered by the same provider and (c) that provider is reimbursed to the rate set by the government, on evidence that the consumer has used the service chosen. I shall neither limit the word 'voucher' only to cases where the consumer carries a physical token to present to a provider, nor to cases where separate physical payments are made for each client, nor to cases where the consumer makes the final decision of service content or of provider without having to make an application to a public authority: where all these conditions are present, one might speak of a 'true' or 'strict' voucher scheme (as in Direct Payments, social care from 1981 to 1993 and nursery vouchers from 1996 to 1997). In this extended sense, however, all of the schemes examined here are ones in which a 'voucher' is attached to the consumer's choice: quotation marks 
are used around the term at the beginning of some sections of the article to make it clear that the broad sense is intended.

The following nine schemes of consumer choice are analysed:

- secondary school choice, introduced in 1988;

- the Nursery Education Vouchers Scheme, introduced in 1996 but abandoned in 1997;

- higher education, where students could always choose both course and institution, but where the levels of public support to students were changed from maintenance grants to loans and, from 1998, loans were introduced for tuition fees;

- choice of GP, which has always existed in some form but which was reformed in 1990;

- choice of hospital consultant, which as yet hardly exists at all, save in the context of joint consultation with one's GP with whom the selection finally rests;

- choice of treatment protocol, which exists mainly to the extent that clinicians offer patients choices, and negatively within the rules on patient consent;

- the Direct Payments scheme, which provides users of personal social services with budgets with which to purchase their own care (Hasler et al., 1999);

- community care, as introduced into law in 1990 but implemented from 1993, whereby a means-tested scheme through the benefits system, where users made relatively unconstrained choices of provider, was replaced by some element of choice at the point of needs assessment and purchase of service by a local authority; and

- offer systems in the allocation of social rented housing, which have traditionally afforded rather limited choice, but which have since 1999 begun to be reformed through the development of Choice-Based Lettings pilot schemes (Department of the Environment, Transport and the Regions, 2000; Department for Transport, Local Government and the Regions, 2001).

Other programmes could have been chosen. For example, the Housing Benefit scheme provides a nearly true voucher for housing costs for tenants in the privately rented housing sector; the Legal Aid scheme provides people on very low incomes with a nearly true voucher for the costs of legal advice on certain problems and, in some cases, representation; the NHS prescription drug scheme provides patients with a 'voucher' for clinically prescribed treatments; each of these is means-tested. There are some schemes to provide subsidies for children and retired people to use railways and buses. However, it proved difficult to identify relevant literature specifically on the consequences of consumer choice of accommodation or solicitor or compliance with prescribed treatment in these programmes. 


\section{Goals}

The goals for which policy makers may introduce individual consumer choice can be classified as follows (cf. Klein and Millar, 1995).

\section{Consumer-level goals}

Goals that are concerned with meeting the needs or demands of consumers can be divided into the following categories:

1. Outcomes. Where there is evidence that having, or having and exercising choice itself has positive benefits for consumers, in respect of the welfare outcomes that government wants to promote, policy may provide choices to that end, for example that exercising choice promotes health (Segal, 1998) or that control over one's life including choosing enhances health (Syme, 1996); for evidence that exercising choice can have positive effects on outcomes in mental health, see Roth and Fonay (1996), Horvath and Symonds (1991), Safran and Muran (1996), all cited in Department of Health (1999: 43). There may be some evidence that exercising some element of choice, jointly with the physician, between treatment options has beneficial effects upon treatment outcomes, at least for some patients and for some conditions (Darkins, 1996, cited in Morgan, 1998: 76, n. 15).

2. Acceptability: Some consumers may subjectively feel that choice is important, and that it is objectively unreasonable that they should be denied choices in a given area. Thus, it may be politically important for government to be seen to offer them those choices (this has been very important in the debate about education vouchers in the US: Chubb and Moe, 1990; Moe, 1995); it may be less important in complex health care issues, at least for some older patients (Beisäcker, 1988).

3. Satisfaction: There are cases where there is evidence that, even controlling for the objective characteristics of a service after choice, consumer satisfaction is raised by consumers having choices, typically about content and level but also of provider (for example, Doty et al., 1996 find this for people with disabilities using personal social services making choices about carers, timing, and use of budgets: the study did not control for objective characteristics of services, and so is not conclusive, but the size of the effect was significant). Where higher levels of reported consumer satisfaction are an important goal, government may want to introduce choices of these kinds. However, there is also evidence that being put into a situation where one has to make a choice, such as having to change one's GP, can reduce satisfaction with services (Inglehart, 1995 cited in Wilton and Smith, 1998); however, even people who feel dissatisfied (personally, or in the short term) because of the burden of choice might still feel that choice was important (generally, or for themselves in the longer term). 
4. User convenience: In some services, some element of consumer choice can hardly be avoided in practice, and while this may hardly be a goal, in practice the service will be organised around this recognition.

\section{Service-level goals}

The most important goals concerned with promoting characteristics of service supply-side systems are those of:

5. Experiment: In this case, choice about content of service is used as a means of finding out which service packages are preferred, by whom, or how far innovations in content attract consumer interest.

6. Responsiveness: Here choice about identity of content or of provider is used in order to promote competition or at least contestability, as a discipline upon providers to offer service content that consumers actually want, in respect both of quality of current service models and innovation in content.

7. Efficiency: Here, choice of provider is offered in order to promote efficiency (lower unit costs for given level of output or higher level of output for given level of cost), by structuring the financial arrangements behind consumer choice to bear down on costs.

8. Clientèle: Here, choice about content and level is offered, in order to keep middle-class consumers from exercising their choice to exit and use private commercial services instead.

9. Presentation: Here, choice is used on a political rather than a technical policy rationale, in order to mask the operation of other goals, for example by offering consumers something in compensation for cuts being made at the same time (Henig, 1994: Chapter 4 and Hassel, 1999 suggest that at state level in the US, this may have been important in some cases in the development, respectively of school choice and charter school initiatives).

Assessing goals is not always easy, for overtly avowed goals may not, of course, be the true goals. Sometimes the avowed goals and the foreseeable consequences of the measures (foreseeable, that is, within what the ideological blinkers of the government of the day would allow) seem to coincide, as in the case of community care where the avowed goal was that of efficiency (Wistow et al., 1994, 1996). Other cases are harder to understand. The 1988 school choice reforms were presented by ministers principally as means for achieving greater diversity and responsiveness of schools to the particular preferences of parents. Yet the simultaneous introduction of the national curriculum and the greater regulation of systems of financial management introduced through the local management scheme, and the introduction of the league table as the principal or even the sole basis for competition together with the greater regulation of local education authorities could all be said to have undermined diversity (Levačić, 1994; Glatter and Woods, 1994; Woods et al., 1998; Gewirtz et al., 1995; 
Whitty et al., 1998; Gorard, 1997). Curriculum diversity could be achieved mainly through specialisation, for example by converting a school into a City Technology College. Choice in nursery vouchers was expected to improve quality and responsiveness (Education and Employment Committee, 1997).

Sometimes goals are not very clear at all: in general, the more modest the level or degree of choice, the less clarity about goals we find: for example in the health field, goals for GP choice were not well articulated by ministers (Klein, 1995), although in giving fundholding GPs choice over hospitals, responsiveness was regarded as important (Robinson and Le Grand, 1993; Le Grand et al., 1998). Therefore, in identifying goals, I have followed explicitly claimed intentions where possible, and reconstructed goals by inference from the foreseeable consequences of scheme design only where this method fails. Where it is difficult to reconstruct goals at all, because systems have persisted for a long time and where the element of choice, being modest, was probably more a matter of administrative convenience than of positive political decision, a question mark is entered after a plausible entry. The first row of Table 1 below presents a plausible reconstruction of goals.

\section{Achievements}

It is not straightforward to determine to what extent the goals have actually been furthered by these programmes of consumer choice. With the important exception of secondary school choice, there are few objective, comprehensive, detailed and rigorous published evaluations of the implementation of consumer choice schemes against their objectives in any of these fields. Table 1 is an attempt to summarise the findings of a large number of researchers reviewing the experience of choice in these fields.

\section{School choice}

School choice has been most extensively researched and evaluated, and in this area there is also an extensive cross-national comparative literature (Woods et al., 1998; Gewirtz et al., 1995; Whitty et al., 1998; Gorard, 1997, 2000a,b; Gorard and Taylor, 2002; Gorard and Fitz, 1998a,b; Noden, 2000; Taylor, 2001; Fiske and Ladd, 2000; Walford, 1996; Adnett and Davies, 2000).

Many writers stress the variation between localities in the experience and extent of choice, the nature of parental preferences, the importance of local history, the entrepreneurship and innovativeness of heads and local philanthropists, and therefore the difficulties of generalising (for example, Taylor, 2001; Adnett and Davies, 2000). This is of course true of each of the fields of public service. The fact and depth of local variation is not to be denied. However, it need not follow that nothing can therefore be said, albeit with qualifications, about how far goals have been achieved. For example, there are many differences in parental involvement and preferences that have more to do with class than 
locality, and that can be observed nationally. The basic dynamics of curriculum regulation, national specification of 'voucher' size, the importance of peer effects in shaping class preferences, the incentive effects of league tables, and relationships between selective and non-selective schools are broadly common, even if the size of the effects of these factors vary significantly by locality. Whilst the full range of local variation cannot of course be represented in tables like those presented here, their modest aim is simply to provide indications of general trends.

Certainly, the school choice scheme appears popular with many parents, and has achieved good satisfaction ratings from majorities. A recent nationally representative cross-sectional survey of children in school years 5 to 7 found high satisfaction rates outside London, both with the process of choice and with the school chosen (Flatley et al., 2001). It is possible, of course, to argue that satisfaction reflects cognitive dissonance reduction, or persistence of and spillover from institutionalised positive attitudes among parents to schools generally (surveys have long reported general satisfaction with schools), but there is no evidence that such factors could be powerful enough to explain the very high proportions satisfied with both in the Flatley et al. (2001) survey.

As noted above, other concomitant policies have limited the extent to which responsiveness and experiment could be elicited. Although we lack any control against which to check the counterfactual hypothesis, the scheme may have contributed to keeping a significant proportion of the middle class within the system, except in London and the south east (Whitty et al., 1998; Flatley et al., 2001). Curriculum innovation, even by specialisation, was modest, and could only be achieved by large, successful schools (Adnett and Davies, 2000). Assessing the impact on efficiency is much more difficult, since the scheme was not introduced in isolation, and many other reforms have affected costs. One largescale quantitative study found that where choice has increased competition locally (the study controlled for the presence of cream-skimming selective schools, but did not control fully for the fact that they may not be competing for the same kinds of pupils, nor could it examine parental choice behaviour directly), this resulted in improvements in efficiency between 1993 and 1997, although it found diversity in the foci of efficiency (Bradley et al., 1999). Here efficiency is defined as joint maximisation of GCSE grade A to $\mathrm{C}$ achievement and attendance rate (one minus the school truancy rate) for a given level of inputs, assuming constant returns to scale; the study measured this on a government data set from the School Performance Tables for all secondary schools in England and other unpublished data specially obtained from the Department for Education and Employment (as it then was) on pupil-teacher ratios, socio-economic background of pupils and LEA expenditure on books, material and teachers and from the National Online Manpower Information Service on socio-economic composition of school districts. 
One key policy problem here is the absence of a very flexible mechanism for market entry in the state sector. While in theory private schools can opt in, few have done so and fewer have been successful. Local authorities can establish new schools but their fiscal constraints mean that they do not always do so at levels that would be considered responsive to changes in consumer demand. The City Academy scheme allows for new schools but even this lacks the flexibility of some of the US states' charter school schemes (Hassel, 1999) or of the Dutch and some Scandinavian countries' schemes that grant groups of parents the right to found new schools and secure public resources for them, subject to certain conditions (Walford, 1996). A second problem is the fact that the 'special measures' system does not always quickly either turn failing schools around or effect their exit. There are, however, important problems with the school choice system that the simple focus on avowed and implicit goals taken in this table does not reveal, but which will be discussed in the next section.

\section{Nursery vouchers}

Because the Nursery Vouchers scheme was terminated so quickly after being introduced, rather little can be said about the extent to which it would have achieved its goals. Indeed, the column on the scheme is only retained in the table in order to give due emphasis to the incoming Labour administration's view that its transaction costs were excessive in proportion to the size of the scheme and any benefits it was likely to have by way of impact on quality or total market sizeall of which may well have been true (cf. Sparkes and West, 1998).

There is evidence that it was not greatly supported by parents. A Central Office of Information and MORI poll in March and April 1996 interviewed 201 parents living in areas where vouchers had first been introduced. Sixty one per cent of those questioned rated the voucher scheme positively and 23 per cent negatively. However, a subsequent MORI survey in the summer of 1996, questioning 605 parents, found 76 per cent saying that it had made no difference to the number of places available and 83 per cent saying that it made no difference to the their ability to exercise their choice of provider (Education and Employment Committee, 1997).

The Education and Employment Committee's (1997) report on the operation of the Nursery Education Voucher Scheme argued that the scheme may haveled to a reduction of parental choice - in the sense of number of available providers to choose between - rather than an increase, and that this should have been expected. For schools entered the market in significant numbers, being better able to expand in response to changes in demand than were local playgroups, and the bulk of the voucher income went to schools for reception classes, not least because the more popular schools used reception class attendance as an admission criterion for subsequent primary education. This caused some private providers to close. However, the report also noted that the evidence was still inconclusive 
about whether provision would increase in future, and how far parents' choice would increase.

\section{Higher education}

Whatever the other problems with that sector, the experience of consumer choice in higher education is arguably the happiest of the nine compared here, at least until recently. The supply side may have seen little market entry, but existing providers have expanded to meet rising demand financed by steadily expanding state funding until the mid-1990s. A recent economic modelling exercise concluded that the market structure as measured by the number of universities was roughly appropriate to the economies of scale estimated to be available with the present technologies of teaching, that there might be a case for a limited number of mergers but that any expansion should take place within existing universities (Johnes, 1997). There has been innovation in courses to the point that educational traditionalists are critical of universities for excessive responsiveness to student preferences and insufficient dirigisme and paternalism. Despite the shift from grant to loans and even the introduction of loans for tuition fees, the middle class has remained solidly within the state subsidised sector, although there may have been a modest reduction in demand since the introduction in 1997 of tuition fees and consequent changes in consumer behaviour and increasing concern among potential students about the risks involved with shouldering the larger debts than previous cohorts of students faced (Dolton et al., 1997; Watson and Bowden, 1999; Parry, 1999; Hesketh, 1999; Ahier, 2000; Archer and Hutchings, 2000).

\section{Health and social care}

Where only modest changes has been attempted, unsurprisingly they have been achieved but with no great enhancement of consumer experience. The very limited direct consumer choice in the NHS, combined with patient inertia over GP choice and continuing willingness to defer decisions to clinicians together mean that, to the extent there were clear goals for consumer choice, they cannot be said to have been achieved.

In studies, many patients are reported to be offered few choices by their GPs, although GPs claim to offer more, and the 1990 reforms appear not to have greatly increased choice (Mahon et al., 1993; Jones et al., 1993; Shackley and Ryan, 1994; Mulligan, 1998; Fotaki, 1998). In the same way, the absence of clear goals for the very limited (and longstanding: Merrett, 1979) element of choice in social rented housing, makes it difficult to say much about achievement.

The Direct Payments scheme, in those areas where it has been implemented adequately, seems to have been broadly popular with those service users who have been offered budget management responsibility (Maglajlic et al., 200o; Clark and Spafford, 2001; Glendinning et al., 2000a,b). However, we still have no rigorous 
large-scale studies on the impact on service users' well-being from exercising these choices.

A recent review of evidence on actual levels of choice in community care for older people (Knapp et al., 2001) found only two studies to report. These, however, were rather discouraging. Wigley et al., 1998, cited in Knapp et al., 2001) found most consumers reporting very little choice. One in-depth study of 24 users in four localities (Hardy et al., 1999a,b) found that in six out of ten cases examined, applicants were given no choice about whether to move into a home: no domiciliary care option was presented at all. In most cases, applicants were given poor quality information about the options with which they were presented. Those who ended up in local authority homes were offered even less information than those who went into private or voluntary sector run homes. No one who did receive domiciliary care was offered a choice presented in terms of sector or provider; few if any were consulted about the composition or even the timing of services. Although most respondents seemed content with the services they were receiving, the study may not have controlled fully for expectations. Most other studies have found that assessment and commissioning continue to be 'service-led', in the jargon of the field - that is to say, needs defined and care purchased on the basis of what has historically been the dominant form of provision (Davis et al., 1997). A picture of at best modest improvement is given in a new study of 55 users, 37 carers and 28 care managers in seven English authorities (Ware et al., forthcoming). This found care managers reporting more provider options in some areas but much less perception of choice among users and carers. Least choice of providers was presented for domiciliary care, and the study found little scope for user choice over content of service: tight eligibility criteria limited choice of content as well as access. In residential care, the greater numbers of options available to care managers than in previous years did not necessarily mean that users were presented with more choices, and many were offered few or none; many also received little information on which to make choices. About 10 per cent of cases where discharge from hospital is delayed are explained by user choice not to accept the care package (or packages) offered (Social Services Inspectorate, 2002). Anecdotal evidence suggests, however, that there is significant choice of residential care provider on offer in major cities and seaside towns.

Table 1 summarises the findings of the literature review on goal achievement.

\section{Problems with consumer choice programmes}

There are also less-fortunate consequences of consumer choice programmes that should probably fairly be regarded as unintended by governments - although, of course, cynics will always be able to claim that governments must surely have foreseen some of the consequences. 
TABLE 1. Achievement of avowed or reconstructed goals in consumer choice programmes.

\begin{tabular}{|c|c|c|c|c|c|c|c|c|c|}
\hline $\begin{array}{l}\text { Field of } \\
\text { choice/goal }\end{array}$ & School choice & $\begin{array}{l}\text { Nursery } \\
\text { vouchers }\end{array}$ & $\begin{array}{l}\text { Higher } \\
\text { education }\end{array}$ & $\begin{array}{c}\text { Choice of } \\
\text { GP }\end{array}$ & $\begin{array}{l}\text { Choice of } \\
\text { consultant }\end{array}$ & $\begin{array}{l}\text { Choice of } \\
\text { treatment }\end{array}$ & $\begin{array}{c}\text { Direct } \\
\text { payments }\end{array}$ & Community care & $\begin{array}{l}\text { Social rented } \\
\text { housing }\end{array}$ \\
\hline $\begin{array}{l}\text { Avowed or } \\
\text { reconstructed } \\
\text { goals for } \\
\text { individual } \\
\text { consumer } \\
\text { choice }\end{array}$ & $\begin{array}{l}\text { Responsiveness, } \\
\text { efficiency } \\
\text { (through } \\
\text { competition, } \\
\text { exit of failing } \\
\text { and expansion } \\
\text { of successful) }\end{array}$ & $\begin{array}{l}\text { Efficiency } \\
\text { (through } \\
\text { encouraging } \\
\text { competition } \\
\text { and entry by } \\
\text { private sector) }\end{array}$ & $\begin{array}{l}\text { Responsiveness? } \\
\text { Outcomes? }\end{array}$ & $\begin{array}{l}\text { None in } \\
\text { particular: } \\
\text { choice } \\
\text { regarded as } \\
\text { inevitable; } \\
\text { at most, } \\
\text { user } \\
\text { convenience }\end{array}$ & $\begin{array}{l}\text { Perhaps } \\
\text { responsiveness? }\end{array}$ & $\begin{array}{l}\text { Patient } \\
\text { acceptability? }\end{array}$ & $\begin{array}{l}\text { Outcomes, } \\
\text { acceptability, } \\
\text { experiment, } \\
\text { responsiveness? }\end{array}$ & $\begin{array}{l}\text { Efficiency } \\
\text { (through exit, entry } \\
\text { by private sector } \\
\text { and competition), } \\
\text { ? outcomes } \\
\text { through more } \\
\text { supported living in } \\
\text { own homes }\end{array}$ & Responsiveness? \\
\hline Outcome & Not known & $\begin{array}{l}\text { Not tried for } \\
\text { long enough }\end{array}$ & $\begin{array}{l}\text { Not known, } \\
\text { but presumed }\end{array}$ & No evidence & $\begin{array}{l}\text { Some } \\
\text { experimental } \\
\text { evidence esp. } \\
\text { psychotherapy }\end{array}$ & $\begin{array}{l}\text { Some } \\
\text { experimental } \\
\text { evidence esp. } \\
\text { psychosomatic } \\
\text { conditions }\end{array}$ & $\begin{array}{l}\text { Some } \\
\text { evidence }\end{array}$ & $\begin{array}{l}\text { Little evidence: } \\
\text { most outcomes } \\
\text { research does not } \\
\text { control for choice } \\
\text { separately }\end{array}$ & $\begin{array}{l}\text { No evidence; } \\
\text { probably not } \\
\text { a meaningful } \\
\text { measure }\end{array}$ \\
\hline Acceptability & $\begin{array}{l}\text { Achieved } \\
\text { for many }\end{array}$ & Not achieved & Achieved & Achieved & Limited & Mixed & Achieved & Achieved & Limited \\
\hline Satisfaction & $\begin{array}{l}\text { Achieved } \\
\text { for many }\end{array}$ & $\begin{array}{l}\text { Not tried for } \\
\text { long enough }\end{array}$ & Achieved & $\begin{array}{l}\text { Achieved } \\
\text { for many }\end{array}$ & Limited & Mixed & Achieved & $\begin{array}{l}\text { Achieved in some } \\
\text { areas, e.g. big cities } \\
\text { and seaside towns }\end{array}$ & Limited \\
\hline Convenience & $\begin{array}{l}\text { Achieved } \\
\text { for some }\end{array}$ & & $\begin{array}{l}\text { Achieved } \\
\text { except in } \\
\text { London and } \\
\text { some other } \\
\text { big cities } \\
\text { (high housing } \\
\text { costs) }\end{array}$ & Achieved & $\begin{array}{l}\text { Limited and } \\
\text { may be } \\
\text { declining as } \\
\text { patients have } \\
\text { to travel } \\
\text { further }\end{array}$ & $\begin{array}{l}\text { Limited and } \\
\text { may be } \\
\text { declining as } \\
\text { patients have } \\
\text { to travel } \\
\text { further }\end{array}$ & Achieved & $\begin{array}{l}\text { Achieved in some } \\
\text { areas, e.g. big cities } \\
\text { and seaside towns }\end{array}$ & Limited \\
\hline Experiment & $\begin{array}{l}\text { Limited by } \\
\text { regulation }\end{array}$ & $\begin{array}{l}\text { Undermined } \\
\text { by school } \\
\text { domination }\end{array}$ & $\begin{array}{l}\text { Significant } \\
\text { evidence }\end{array}$ & Little & No impact & $\begin{array}{l}\text { Present but } \\
\text { not response } \\
\text { to choice }\end{array}$ & $\begin{array}{l}\text { Too small } \\
\text { scale to tell: } \\
\text { may be at the } \\
\text { margin }\end{array}$ & $\begin{array}{l}\text { Limited: financial } \\
\text { pressures de facto } \\
\text { worked against } \\
\text { non-residential } \\
\text { care in many areas }\end{array}$ & $\begin{array}{l}\text { Negligible: any } \\
\text { incentives for } \\
\text { innovation are } \\
\text { administrative }\end{array}$ \\
\hline Responsiveness & $\begin{array}{l}\text { Limited by } \\
\text { regulation }\end{array}$ & Limited & Achieved & Limited & Little & $\begin{array}{l}\text { Present but } \\
\text { not response } \\
\text { to choice }\end{array}$ & $\begin{array}{l}\text { Too small } \\
\text { scale to tell: } \\
\text { maybe at the } \\
\text { margin }\end{array}$ & $\begin{array}{l}\text { Limited: financial } \\
\text { pressures de facto } \\
\text { worked against } \\
\text { non-residential } \\
\text { care in many areas }\end{array}$ & Negligible \\
\hline
\end{tabular}




\begin{tabular}{|c|c|c|c|c|c|c|c|c|c|}
\hline Efficiency & $\begin{array}{l}\text { Some } \\
\text { achievement, } \\
\text { but little } \\
\text { market entry } \\
\text { Limited } \\
\text { evidence on } \\
\text { costs } \\
\text { Competition } \\
\text { limited by } \\
\text { polarisation } \\
\text { and } \\
\text { congestion at } \\
\text { top of market }\end{array}$ & $\begin{array}{l}\text { High } \\
\text { transaction } \\
\text { costs }\end{array}$ & $\begin{array}{l}\text { Increased } \\
\text { supply by } \\
\text { existing } \\
\text { universities } \\
\text { Limited entry } \\
\text { or exit } \\
\text { some } \\
\text { evidence of } \\
\text { cost control }\end{array}$ & $\begin{array}{l}\text { No } \\
\text { evidence } \\
\text { of gain }\end{array}$ & $\begin{array}{l}\text { Not sufficient } \\
\text { incentive }\end{array}$ & $\begin{array}{l}\text { Not sufficient } \\
\text { incentive }\end{array}$ & Unknown & $\begin{array}{l}\text { Some competition } \\
\text { in residual care } \\
\text { in cities and } \\
\text { seaside towns; less } \\
\text { in domiciliary; } \\
\text { main incentives } \\
\text { from economy } \\
\text { from cash ceilings }\end{array}$ & $\begin{array}{l}\text { No evidence of } \\
\text { any impact }\end{array}$ \\
\hline $\begin{array}{l}\text { Clientèle } \\
\text { retention }\end{array}$ & $\begin{array}{l}\text { Some } \\
\text { achievement } \\
\text { except SE } \\
\text { England }\end{array}$ & $\begin{array}{l}\text { Not tried for } \\
\text { long enough or } \\
\text { with sufficient } \\
\text { increase in } \\
\text { resources }\end{array}$ & Achieved & $\begin{array}{l}\text { Middle- } \\
\text { class } \\
\text { clientele } \\
\text { exit } \\
\text { unlikely in } \\
\text { any case }\end{array}$ & $\begin{array}{l}\text { Not } \\
\text { significant } \\
\text { incentive: exit } \\
\text { for elective } \\
\text { surgery } \\
\text { growing in } \\
\text { any case }\end{array}$ & $\begin{array}{l}\text { Not } \\
\text { significant } \\
\text { incentive: exit } \\
\text { for elective } \\
\text { surgery } \\
\text { growing in } \\
\text { any case }\end{array}$ & $\begin{array}{l}\text { Not relevant: } \\
\text { exit } \\
\text { impossible } \\
\text { for many in } \\
\text { these client } \\
\text { groups }\end{array}$ & $\begin{array}{l}\text { Some evidence for } \\
\text { achievement }\end{array}$ & Not relevant \\
\hline Sources & $\begin{array}{l}\text { Gewirtz et al., } \\
\text { 1995; Glatter } \\
\text { and Woods, } \\
\text { 1994; Woods } \\
\text { et al., 1998; } \\
\text { Gorard, 1997; } \\
\text { Kendall and } \\
\text { Holloway } \\
\text { 2001; } \\
\text { Walford, } \\
\text { 1996; Levačić, } \\
\text { 1994; Whitty } \\
\text { et al., 1998; } \\
\text { David et al., } \\
\text { 1994; Flatley } \\
\text { et al., 2001 }\end{array}$ & $\begin{array}{l}\text { Education and } \\
\text { employment } \\
\text { committee, } \\
\text { 1997; Sparkes } \\
\text { and West, } 1998\end{array}$ & $\begin{array}{l}\text { Ahier, 2000; } \\
\text { Watson and } \\
\text { Bowden, } \\
\text { 1999; Dolton } \\
\text { et al., 1997; } \\
\text { Johnes, 1997; } \\
\text { Hesketh, } \\
\text { 1999; } \\
\text { Middleton, } \\
\text { 2000; Parry, } \\
\text { 1999; Power, } \\
2000\end{array}$ & $\begin{array}{l}\text { Charny } \\
\text { et al., 1990; } \\
\text { Shackley } \\
\text { and Ryan, } \\
\text { 1994; } \\
\text { Fotaki, } \\
\text { 1998; } \\
\text { Goodwin } \\
\text { 1998; } \\
\text { Glennerster } \\
\text { et al., } 1994\end{array}$ & $\begin{array}{l}\text { Mahon et al., } \\
\text { 1993; Jones } \\
\text { et al., } 1993\end{array}$ & $\begin{array}{l}\text { Mahon et al., } \\
\text { 1993; Jones } \\
\text { et al., } 1993\end{array}$ & $\begin{array}{l}\text { Hasler et al., } \\
\text { 1999; } \\
\text { Maglajlic et al., } \\
\text { 2000; } \\
\text { Clark and } \\
\text { Spafford } \\
\text { 2001; } \\
\text { Glendinning } \\
\text { et al., 200a,b }\end{array}$ & $\begin{array}{l}\text { Knapp et al., 2001; } \\
\text { Wistow et al., 1994, } \\
\text { 1996; Wigley et al., } \\
\text { 1998; Bland, 1999; } \\
\text { Ware et al., } \\
\text { forthcoming }\end{array}$ & $\begin{array}{l}\text { DETR, 2001; } \\
\text { DTLR, 2001; } \\
\text { Clapham and } \\
\text { Kintrea, 1986; } \\
\text { Pawson and } \\
\text { Kearns, } 1998\end{array}$ \\
\hline
\end{tabular}


The social policy literature is bulging with very diverse taxonomies and discussions of problems with consumer choice programmes. In order to introduce some order into the discussion, some forcing of material into a taxonomy and perhaps even some arbitrariness in selecting priority problems is unavoidable. In focusing on the three categories of problems, Table 2 attempts to mitigate these problems by taking categories from the literature wherever possible, and by selecting problems on each of what appear to be the three main areas. These are problems of distributional process and outcome (coded D), problems of efficiency (coded E) (one problem at least has had to be given both codes: no doubt there is a case that others could be too), and problems of political risk (coded P) by which is meant the possibility that politicians and professionals may be subject to embarrassment and criticism in the media or from interest groups for allowing some consumers to rely on public funds when they choose certain services that may be deemed by others to be 'bad', 'frivolous', 'inappropriate' or 'ineffective' choices.

\section{Distributional outcomes: polarisation}

The literature on school choice shows the greatest concern with problems with zero-sum distributional outcomes (Fiske and Ladd, 2000; Walford, 1996; Woods et al., 1998; Gordon, 1996; Gorard, 2000a,b; Gorard and Taylor, 2002; Gorard and Fitz, 1998a,b; Noden, 2000; Taylor, 2001). Polarisation can be defined as the situation in which the market separates into a 'sink' sub-sector of underperforming suppliers located in disadvantaged areas unable to attract good staff and for which there are falling levels of consumer demand and no competition between consumers for access, and an 'élite' sub-sector of high-performing suppliers located in wealthy, leafy areas able to attract good staff, with high levels of applications, where there is congestion, and where in effect the suppliers choose the consumers. Where there are no mechanisms in the overall policy mix to compensate for this, the risks are that the worse schools get worse, the best expand to the limit of their capacity but no further, and the life chances of those who are unable to get into the best schools are systematically reduced with consequent negative effects upon the possibilities for meritocracy and social mobility in the higher education sector and the labour market, and for social closure among educational 'classes', as well as for polarisation in housing market values which comes to be heavily driven by school selection rules that use geographical catchment areas. The result, where this occurs, is that parents in each sector feel that they either have no choices or else that their choices are of no great value to them.

This problem has been found to be most severe in New Zealand (Fiske and Ladd, 2000; Ladd and Fiske, 2001; Gordon, 1996; Waslander and Thrupp, 1995). In the UK, there is dispute about how serious the problem is. Certainly, prior to school choice being introduced, there was and since then there has continued 
to be great polarisation: choice has done rather little to break the link between class and educational outcome, as even its defenders admit (Gorard and Taylor, 2002). Gorard and Fitz (1998a,b) argue that polarisation may have worsened initially as middle-class parents quickly learned to use the new system, but, as other families learned, the effect moderated (the so-called 'starting gun hypothesis'). Other ways of calculating the trend data, which can be argued to be superior, suggest a steady but very modest increase in polarisation (Noden, 2000). Certainly, there is still a spectrum of middling schools in much of the UK. However, a number of qualitative studies have diagnosed polarisation, especially in London and the south east (Woods et al., 1998; Flatley et al., 2001; Walford, 1996; Glatter and Woods, 1994): some quantitative studies using simple percentage changes have found polarisation (Gibson and Asthana, 1999), but the appropriateness of such numbers has been challenged as being insensitive to size of population and overly sensitive to marginal effects (Gorard, 2000a,b). On the other hand, Gorard and Fitz's apparently consoling calculations may underestimate the exacerbating role of peer effects (Noden, 2000: 376).

Probably, regulation of curriculum and inspection of school performance have moderated polarising tendencies. It is at least possible that the problem might be reduced further if there were more effective mechanisms for market entry into the state sector - as in the US, where the charter school movement has provided some element of entry (Hassel, 1999) - and if more effective means could be found for tackling the seemingly intractable problem of ensuring faster exit for failing schools with reallocation of pupils or else turning around failing schools, for the first would perhaps relax the zero-sum character of the competition, while the second might limit the damage to those locked into what can become a 'sink' sub-sector.

The problem of zero-sum polarisation is probably also exacerbated by several other problem factors, including the presence of segregationist preferences among more affluent parents, the inertial effect of the preferences of some parents with children in under-performing schools, and the possibility that the financial size of the 'voucher' compensation for disadvantage may be inadequate to create a sufficient incentive for good schools to compete for these children, and to attract the best teachers to work with them; high transaction costs, where these are a problem, may also be a contributing factor. However, for the purposes of making comparisons between services, these can and should be treated independently. Unfortunately, the presence and scale of most of these factors have been much more comprehensively treated in the education and health literatures than in other fields of social policy.

\section{Segregationist preferences}

There have been well-publicised cases of segregationist preferences taking the form of racism in some school areas, including a major conflict in Dewsbury in the 
1980s (Gorard, 1997: Chapter 1), and various suggestions that the riots in several northern towns and cities during 2001 may reflect segregationist preferences in schooling and housing (closely linked in any case). Gewirtz et al. (1995) found parents expressing distaste for their children being schooled alongside 'rougher elements', which they interpret as code for segregationist preferences at least by class if not necessarily by race. Some studies find that some middle-class parents actively avoid choosing schools with disadvantaged intakes (West et al., 1998). Perhaps segregationist preferences will always out sooner or later, even in schemes where choice is administratively limited, but differently designed choice schemes will give expression to those preferences in different ways. However, segregationist preferences may simply reflect an intuitive appreciation of the value of effects of peer influence on children: unfortunately, the value of these has been found to be much greater for low-ability than for high-ability children Zimmer and Toma, 2000) and perhaps even damaging for high-ability children (Argys et al., 1996), making segregation doubly damaging to egalitarian aspirations for distributional outcomes.

In higher education, there has certainly always been an element of segregationist preference by social class and other ascribed identities (Ball et al., 2002; Power, 2000), but it may be that the general expansion in funding and supply until 1997 and the improvement in academic quality of socially less-prestigious universities has in recent decades acted to compensate for any segregationist effect: for in general, segregationist preferences are less damaging in positive-sum contexts and where the relatively greater value of the services preferred by high-status segregationist choosers is being eroded. Again, the enhancement of regulation of university teaching during the 1990s may have limited any forces for polarisation (Dolton et al., 1997: 715; Middleton, 2000).

Interestingly, a mid-1980s study on take-up of offers in social rented housing found that segregationist preferences did have a damaging distributional effect upon the quality of homes occupied by less-advantaged tenants (Clapham and Kintrea, 1986). A more recent study of allocation policies for hard-to-let properties suggests that the scale of that effect may be rather less now, perhaps partly as a result of points-based lettings schemes (Pawson and Kearns, 1998). The new pilot projects for Choice-Based Lettings schemes are to be designed, according to central government guidance, not only to allow more choice, but also to allow different generations of the same family to live near to each other once again (Department for Transport, Local Government and the Regions, 2001). In the 1980 os these 'sons and daughters policies' were vigorously challenged on equal opportunities grounds as effectively ways of preserving the predominantly white character of certain areas, and the analysis of the 2001 riots in the northern towns has suggested that geographical segregation in housing may have been a contributor factor to lack of inter-communal understanding and trust. It remains 
to be seen whether the effect Clapham and Kintrea detected in the mid-1980s will be increased by Choice Based Lettings.

In other services, disadvantage arising through segregation is certainly not uncommon but tends not to be an effect of consumer preferences. For example, there are some ways in which in health care the size of the inverse care law effect (that those who need the most and the best health care get the least and the poorest: Tudor Hart, 1971) may partly reflect segregationist preferences among some clinicians, but is probably not generally greatly affected by segregationist preferences among patients about the kinds of other people with whom they are willing to share the waiting room.

\section{Cream skimming, adverse selection and adequacy of 'voucher' differentials}

There are fields or markets in which, despite the ability of consumers to back their choices with a publicly financed 'voucher', suppliers can still engage in cream-skimming selection between consumers, and, where this is uncompensated, it can lead to adverse selection. Cream-skimming incentives are often greatest where suppliers are rewarded for recording good crude outcome states in consumers' health or training or whatever, rather than for value added. This is a well-documented and significant problem in schools, especially for those schools with high levels of applications that can afford to choose pupils likely to perform well academically, not present discipline problems, and not have health or pastoral problems (Woods et al., 1998). Views differ about the scale of the cream-skimming activity of GPs in patient list management, but one major mid-1990s study found that it was smaller than expected even when, under the fundholding scheme, it might have been thought that both the incentives and ability to skim the cream would have been at their greatest (Glennerster et al., 1994; Matsaganis and Glennerster, 1994). A recent review concludes that the stoploss insurance scheme which provided that health authorities would reimburse fundholding GPs for patients with higher than threshold costs, and the limited personal financial exposure of GPs, meant that, despite early anxieties, there was little cream skimming (Goodwin, 1998: 57-8). There is anecdotal evidence that housing associations, despite their new role in providing housing for the poorest as a result of the transfer of local authority housing, continue to attempt to select tenants in way that leave the most disadvantaged with worse choices, and sometimes only with the residual local authority sector, but no comprehensive studies on this have been found.

Debates about the adequacy of voucher differentials to compensate for disadvantage are, as one would expect in such a politically salient area, never settled empirically, for each side can appeal to different criteria and measures, as well as to different preferred ideal models (Bowles and Gintis, 1996; Le Grand, 1989; Brighouse, 2000; Moe, 1995; Hoxby, 2001). In the health care field, any 
remaining cream-skimming incentives for GPs due to inadequate differentials have probably been reduced since 1997 . In community care, there is some evidence that differentials for severe disability are not adequate in many areas (Wistow et al., 1996; Knapp et al., 2001); one problem with the Direct Payments scheme is that the formulae used to calculate budgets vary greatly by locality and individual, making it difficult to assess adequacy (Glendinning et al., 2000a: 199).

Again, however, the education field is the one with the richest body of research. The basis on which the capitation fees for schools in the UK are calculated has changed since 1988, but, within the local authority sub-sector, where the greatest variations in ability and disadvantage are to be found, central government's leverage is limited by the fact that it can typically only give fiscal incentives to local education authorities to use the recommended figures on the basis of which government calculates the proportion of grant aid for education. Local education authorities retain some discretion, although regulation does put a minimum figure on what local education authorities can allocate to schools. This means, although the nationally set formula has a redistributive and compensating effect (Levačić, 1994: 38-40), the degree of differentiation in the size of per-pupil payment to compensate for disadvantage varies between authorities, and, nationally, it is argued by some experts not to be large enough (Glennerster, 1998: 58ff; Glennerster, 1992: 208). The same experts also note that the elasticity to additional resources of schools' productive effort with the most disadvantaged clientèles, as measured by changes in educational qualifications achieved, is depressingly low; therefore regulatory changes to the exit system would be required, for differential weighting of vouchers may be insufficient to compensate for disadvantage (Glennerster, 1993: 194). Most studies on which that argument is based were conducted prior to the introduction of parental choice (see those reviewed in Glennerster, 1993: 194).

One could argue that the introduction of school choice should have disciplined schools to improve their productivity, and perhaps even in ways that would raise the qualifications outcome elasticity to additional resources for disadvantaged pupils (Hoxby, 2001). However, the theoretical models (including Hoxby's) on which that possibility is based tend to assume that

- schools are competing with each other, whereas there is evidence that many do not need to compete greatly;

- that schools compete on academic qualifications achieved alone, despite the evidence that many parents in fact choose schools on other criteria;

- that they tend not to take account of cream skimming, when again there is evidence to the contrary; and that

- schools maximise on their goals, when this may well not be the case.

Moreover, too many still model the redistributive effect of differential weighting of vouchers by, for example, household income, without making sufficiently 
realistic assumptions about the differential elasticity of the supply-side response (for example, Bearse et al., 2000).

Indeed, to the extent that the parents of the least advantaged are least likely to choose on the basis of academic achievements alone, and to the extent that schools serving these groups are least likely to be able to compete on these terms, the likelihood of a positive effect from choice alone is reduced. Moreover, there are many ways that schools could increase productivity, and increasing educational value added as measured by qualifications for the least-advantaged pupils is only one, and not necessarily the most likely. Schools that satisfice, rather than maximise, are more likely - if competitive conditions will allow this, and typically they will - to improve productivity by controlling costs for the same level of output (value added, qualifications and grades for pupils, etc.), rather than trying to increase output for the same level of cost. Bradley et al., 1999 find a variety of efficiency practices, partly in response to differences in local competitive conditions.

The introduction of tuition fee loans in higher education in 1998 may have exacerbated the problem of voucher inadequacy for the least advantaged. More generally, the problem of consumers being chosen rather than choosing also arises in respect of voucher-issuers as well as in respect of producers. The discretionary nature of the implementation of the Direct Payment scheme may have created problems of this kind in the selection of service users for budgetholding (Maglajlic et al., 2000; Clark and Spafford, 2001).

\section{Transaction costs}

Differential weighting of vouchers, while certainly justifiable and perhaps mandatory on grounds of equity, always has high transaction costs, for voucherissuing agencies who must obtain, process, check and make decisions using a great deal of information about individuals in order to determine which category in the system of triage their needs or disadvantage fall into, for producers who must reclaim costs under the system, and for consumers who must work out how to use the system and how to present themselves in order to secure the best trade-off between voucher size and stigma.

In general, the more conscientious choosers - who tend to be better off in absolute terms and so better able to absorb the time and travel costs involved in such choice - are less deterred by these transaction costs. A number of studies have shown these transaction costs for consumers to be an important factor in both efficiency and distributional outcomes in school choice (Gewirtz et al., 1995; Woods et al., 1998; Gorard, 1997; David et al., 1994). It is also a well-known problem in higher education choice, but the factors in that field that to some degree compensate for cream skimming and prevent zero-sum polarisation mean that these transaction costs for consumers do not create such great problems. Studies of the community care field have shown that transaction costs for 
voucher-issuing bodies in local government and for suppliers are significant (Wistow et al., 1994, 1996; Knapp et al., 2001); Glendinning et al., 2000a,b find high transaction costs for consumers in administering Direct Payments, especially in hiring personal assistants. In the case of GPs list management, it is hard to tell whether the additional administrative burden of handling differential voucher sizes for different patients alone represents a major problem, for other administrative responsibilities have also increased.

\section{Political risks}

Political risks arising from 'embarrassing' choices made by consumers using public funds have sometimes been a problem in some areas with the use of Direct Payments for, for example, aromatherapy or reflexology (Glendinning et al., 2000a: 197), which has attracted adverse local media comment (Maglajlic et al., 2000), and has been a problem for the few remaining 'progressive' schools in the state sector, and for some kinds of courses in the higher education sector. In health care, the political risks have been contained by the growing centralisation of the rationing system through NICE and the evidence-based medicine movement, although, at various times, in vitro fertilisation, some psychotherapeutic services, some cosmetic surgical procedures and orthodontistry on the NHS have attracted adverse media comment and specific rationing (Redmayne, 1995).

Table 2 summarises the findings of the review of the literature on these problems.

\section{Trends and variations in consequences of consumer choice between services}

On the evidence of the literature reviewed here, there is remarkable variation between the nine fields in the UK, in what has been attempted, in what has been achieved, and in the incidence of the problems encountered.

Table 1 shows that there is also great variation in the degree to which the goals have been achieved. Space does not permit adequate examination here of the power of the main alternative explanation for the variation in goal achievement. However, promising lines of enquiry would include consideration of how far those areas marked by under-achievement are ones in which fundamental design problems are found in the programme that would have led to failure applied to any field, and of how far field-specific factors to do with the nature of consumer preferences or the nature of the goods and services over which choice might be exercised can explain these differences.

\section{Efficiency}

In general, this analysis suggests that there has often been greater success in securing responsiveness than in securing efficiency, if, within efficiency, we 
include both static productive efficiency (bearing down on unit costs) and some factors that should make for static allocative efficiency, such as ensuring that consumers choose suppliers and not the other way around.

In school choice, Bradley et al. (1999) find that greater competition from nonselective schools does elicit greater efficiency, that the effect has increased over time as the choice scheme becomes institutionalised, and that competition from closet rivals has the greatest effect: they measured competition by the number of schools between two radii centred around a given school for 1, 2 and 5 kilometres. The study measured the effect of selective schools' cream skimming leaving the less-able and motivated pupils to other schools reducing their absolute GCSE pass output: in fact, the efficiency-reducing effect was small and often not statistically significant. However, polarisation limits competition, unless regulation limits its effects.

Securing responsiveness and innovation seem most likely to be achieved in areas such as higher education where at least between 1988 and 1997, the rationing restrictions were relaxed to support expansion, where there is regulation of process (for example, a focus on teaching quality) rather than of content (for example, the absence of any national curriculum type direct restrictions on content innovation in the higher education sector) and where there are no financial disincentives that militate against innovation (for example, universities faced nothing like the fiscal rules that local authorities introduced, partly in response to central government rules, that militated against supporting as fast a growth in domiciliary care as the 1989 white paper promised). Importantly, if productive efficiency in the university teaching sector is measured - as policy makers do typically measure it - by staff-student ratios, then during the 1990 period of expansion and innovation in courses, efficiency also increased, suggesting that there is no necessary trade-off, at least in the short run, between responsiveness and efficiency, at least on those measures. Of course, if it is true that, despite the evidence from the teaching quality assessment system, high staff-student ratios have significantly reduced teaching quality in ways masked by grade inflation and if it is true - as some pundits have suggested using anecdotal evidence - that new subjects are often not well taught, then it might be necessary to revise this judgment; however, these things have not yet been shown.

Productive efficiency, at least on some measures, can be achieved in the short run by bearing down on voucher size. This seems to have been the case in residential care financing during the 1990s where rates were held down in many areas from about 1996 if not before, until perhaps 2002, when 'market stabilisation' became the policy (Department of Health, 2002). There is continuing and unresolved controversy, however, about how far this resulted in a net loss of beds and of homes, over and above the rate of closure that would have occurred had local authority rates per person risen slightly more generously over that period: a pessimistic view, held of course by the residential care industry bodies, 
TABLE 2. Unintended problems with consumer choice programmes in the UK.

\begin{tabular}{|c|c|c|c|c|c|c|c|c|c|}
\hline $\begin{array}{l}\text { Field of } \\
\text { choice/ } \\
\text { problem type }\end{array}$ & School choice & $\begin{array}{l}\text { Nursery } \\
\text { vouchers }\end{array}$ & $\begin{array}{l}\text { Higher } \\
\text { education }\end{array}$ & $\begin{array}{l}\text { Choice } \\
\text { of GP }\end{array}$ & $\begin{array}{l}\text { Choice of } \\
\text { consultant }\end{array}$ & $\begin{array}{l}\text { Choice of } \\
\text { treatment }\end{array}$ & $\begin{array}{c}\text { Direct } \\
\text { payments }\end{array}$ & $\begin{array}{l}\text { Community } \\
\text { care }\end{array}$ & $\begin{array}{l}\text { Social rented } \\
\text { housing }\end{array}$ \\
\hline $\begin{array}{l}\text { D: Zero-sum } \\
\text { polarisation }\end{array}$ & $\begin{array}{l}\text { Potentially } \\
\text { quite severe; } \\
\text { may be limited } \\
\text { by regulation; } \\
\text { prior polarisa- } \\
\text { tion was in } \\
\text { any case } \\
\text { severe }\end{array}$ & $\begin{array}{l}\text { Not tried for } \\
\text { long enough } \\
\text { to tell }\end{array}$ & Slight & $\begin{array}{l}\text { Not } \\
\text { severe }\end{array}$ & $\begin{array}{l}\text { Not } \\
\text { severe }\end{array}$ & Not severe & No & $\begin{array}{l}\text { May be a } \\
\text { small } \\
\text { problem in } \\
\text { some parts } \\
\text { of residential } \\
\text { care }\end{array}$ & $\begin{array}{l}\text { Some } \\
\text { evidence }\end{array}$ \\
\hline $\begin{array}{l}\text { D: Segregationist } \\
\text { consumer choice } \\
\text { within publicly } \\
\text { financed sector }\end{array}$ & $\begin{array}{l}\text { Significant, } \\
\text { severe in some } \\
\text { areas esp. SE } \\
\text { England, but } \\
\text { always true }\end{array}$ & $\begin{array}{l}\text { Not tried for } \\
\text { long enough } \\
\text { to tell }\end{array}$ & $\begin{array}{l}\text { Significant, but } \\
\text { not severe; may } \\
\text { be partly } \\
\text { compensated by } \\
\text { regulation of } \\
\text { teaching quality }\end{array}$ & May be some & Unlikely & $\begin{array}{l}\text { Not } \\
\text { relevant }\end{array}$ & $\begin{array}{l}\text { Not } \\
\text { relevant }\end{array}$ & $\begin{array}{l}\text { May be } \\
\text { some in } \\
\text { residential } \\
\text { care }\end{array}$ & $\begin{array}{l}\text { Some evidence: } \\
\text { too early to tell } \\
\text { re Choice- } \\
\text { based lettings } \\
\text { schemes }\end{array}$ \\
\hline $\begin{array}{l}\text { D: Uncompensated } \\
\text { cream-skimming } \\
\text { by suppliers }\end{array}$ & $\begin{array}{l}\text { Significant } \\
\text { problem in } \\
\text { some areas }\end{array}$ & $\begin{array}{l}\text { May have } \\
\text { been } \\
\text { important }\end{array}$ & $\begin{array}{l}\text { Not a severe } \\
\text { problem; may } \\
\text { have been worse } \\
\text { re Oxford and } \\
\text { Cambridge prior } \\
\text { to } 1988\end{array}$ & $\begin{array}{l}\text { Probably } \\
\text { limited }\end{array}$ & Limited & $\begin{array}{l}\text { May be } \\
\text { relevant }\end{array}$ & $\begin{array}{l}\text { Not } \\
\text { relevant }\end{array}$ & $\begin{array}{l}\text { May be } \\
\text { significant }\end{array}$ & $\begin{array}{l}\text { Some evidence } \\
\text { for RSLs, and } \\
\text { some LAs } \\
\text { against } \\
\text { homeless }\end{array}$ \\
\hline $\begin{array}{l}\text { D: Inadequate } \\
\text { differential } \\
\text { voucher } \\
\text { compensation for } \\
\text { individual } \\
\text { disadvantage }\end{array}$ & $\begin{array}{l}\text { May be } \\
\text { significant }\end{array}$ & $\begin{array}{l}\text { May have } \\
\text { been } \\
\text { important }\end{array}$ & $\begin{array}{l}\text { Probably limited } \\
\text { prior to } 1998 \\
\text { introduction of } \\
\text { tuition fee loans }\end{array}$ & $\begin{array}{l}\text { Even less } \\
\text { significant even } \\
\text { than under } \\
\text { internal market }\end{array}$ & $\begin{array}{l}\text { Not } \\
\text { important }\end{array}$ & $\begin{array}{l}\text { Probably } \\
\text { limited }\end{array}$ & $\begin{array}{l}\text { May be } \\
\text { important, } \\
\text { but too } \\
\text { early to tell }\end{array}$ & $\begin{array}{l}\text { Significant } \\
\text { in respect } \\
\text { of some } \\
\text { disabilities }\end{array}$ & Not relevant \\
\hline $\begin{array}{l}\text { D/E: Producers } \\
\text { choose consumers }\end{array}$ & $\begin{array}{l}\text { Severe, at top } \\
\text { of market }\end{array}$ & Significant & $\begin{array}{l}\text { Important } \\
\text { phenomenon, } \\
\text { but not } \\
\text { considered a } \\
\text { problem, or at } \\
\text { least partially } \\
\text { compensated }\end{array}$ & Limited risk & $\begin{array}{l}\text { May be } \\
\text { significant }\end{array}$ & $\begin{array}{l}\text { Not } \\
\text { relevant }\end{array}$ & $\begin{array}{l}\text { Significant } \\
\text { problem } \\
\text { due to } \\
\text { discretionary } \\
\text { nature of } \\
\text { eligibility } \\
\text { for scheme }\end{array}$ & $\begin{array}{l}\text { May be } \\
\text { significant }\end{array}$ & $\begin{array}{l}\text { May become } \\
\text { more } \\
\text { significant as } \\
\text { RLs replace } \\
\text { local } \\
\text { authorities }\end{array}$ \\
\hline
\end{tabular}




\begin{tabular}{|c|c|c|c|c|c|c|c|c|c|}
\hline $\begin{array}{l}\text { E: Lack of } \\
\text { market entry }\end{array}$ & Severe problem & $\begin{array}{l}\text { No: schools } \\
\text { entered } \\
\text { rapidly }\end{array}$ & $\begin{array}{l}\text { Small problem, } \\
\text { offset by strong } \\
\text { capability of } \\
\text { existing } \\
\text { universities to } \\
\text { expand in } \\
\text { response to } \\
\text { demand } \\
\text { expansion }\end{array}$ & $\begin{array}{l}\text { Problems, but } \\
\text { not arising from } \\
\text { consumer choice }\end{array}$ & $\begin{array}{l}\text { Problems, } \\
\text { but not } \\
\text { arising from } \\
\text { consumer } \\
\text { choice }\end{array}$ & Not relevant & $\begin{array}{l}\text { Not important } \\
\text { in most areas: } \\
\text { in future, there } \\
\text { may be labour } \\
\text { shortages for } \\
\text { certain helper } \\
\text { roles }\end{array}$ & $\begin{array}{l}\text { Significant } \\
\text { problem in } \\
\text { domiciliary } \\
\text { care in some } \\
\text { areas }\end{array}$ & $\begin{array}{l}\text { Entry by RSLs } \\
\text { is mainly } \\
\text { response to } \\
\text { administrative } \\
\text { measures, not } \\
\text { consumer } \\
\text { choice }\end{array}$ \\
\hline $\begin{array}{l}\text { E: Lack of exit: } \\
\text { consumers locked } \\
\text { into failing } \\
\text { suppliers }\end{array}$ & $\begin{array}{l}\text { Significant, } \\
\text { despite } \\
\text { administrative } \\
\text { 'special } \\
\text { measures' }\end{array}$ & $\begin{array}{l}\text { Not tried for } \\
\text { long enough } \\
\text { to tell }\end{array}$ & $\begin{array}{l}\text { Relatively small } \\
\text { problem }\end{array}$ & Not known & $\begin{array}{l}\text { Possibly } \\
\text { important }\end{array}$ & No & No & $\begin{array}{l}\text { May be a } \\
\text { problem in } \\
\text { some areas }\end{array}$ & $\begin{array}{l}\text { Significant } \\
\text { problem }\end{array}$ \\
\hline $\begin{array}{l}\text { E: High } \\
\text { transaction costs } \\
\text { for consumers, } \\
\text { producers, } \\
\text { financing agency }\end{array}$ & $\begin{array}{l}\text { Significant } \\
\text { problem for } \\
\text { more } \\
\text { conscientious } \\
\text { choosers }\end{array}$ & $\begin{array}{l}\text { Significant } \\
\text { problem for } \\
\text { suppliers }\end{array}$ & $\begin{array}{l}\text { Moderately high } \\
\text { for consumers } \\
\text { and suppliers }\end{array}$ & $\begin{array}{l}\text { Part of wider } \\
\text { problem of } \\
\text { administrative } \\
\text { burden on } \\
\text { suppliers }\end{array}$ & $\begin{array}{l}\text { Not } \\
\text { important }\end{array}$ & Not relevant & $\begin{array}{l}\text { Too early to } \\
\text { tell: at present, } \\
\text { seems } \\
\text { containable }\end{array}$ & $\begin{array}{l}\text { Some evidence } \\
\text { of burden for } \\
\text { some suppliers }\end{array}$ & $\begin{array}{l}\text { Significant } \\
\text { costs for LA } \\
\text { suppliers in } \\
\text { administering } \\
\text { points schemes }\end{array}$ \\
\hline $\begin{array}{l}\text { E: Weak } \\
\text { incentives for } \\
\text { consumers to } \\
\text { shop around for } \\
\text { more economical } \\
\text { option }\end{array}$ & No & No & No & $\begin{array}{l}\text { Observed, but } \\
\text { may not be } \\
\text { important }\end{array}$ & $\begin{array}{l}\text { May be } \\
\text { significant }\end{array}$ & $\begin{array}{l}\text { May be } \\
\text { significant }\end{array}$ & & $\begin{array}{l}\text { Significant } \\
\text { problem in } \\
\text { residential care }\end{array}$ & $\begin{array}{l}\text { Significant } \\
\text { problem }\end{array}$ \\
\hline $\begin{array}{l}P \text { : Political risks } \\
\text { from financing } \\
\text { choices unpopular } \\
\text { with others }\end{array}$ & $\begin{array}{l}\text { Only at the } \\
\text { margin for some } \\
\text { stigmatised faith } \\
\text { schools, } \\
\text { surviving } \\
\text { 'progressive'. } \\
\text { schools, etc }\end{array}$ & No & $\begin{array}{l}\text { At the margin } \\
\text { for some } \\
\text { courses }\end{array}$ & No & No & $\begin{array}{l}\text { At the } \\
\text { margin, } \\
\text { mainly for } \\
\text { IVF, some } \\
\text { elective } \\
\text { cosmetic } \\
\text { procedures }\end{array}$ & $\begin{array}{l}\text { Some evidence } \\
\text { re alternative } \\
\text { therapies }\end{array}$ & $\begin{array}{l}\text { Only important } \\
\text { in occasional } \\
\text { scandal }\end{array}$ & No \\
\hline
\end{tabular}

Problems, but Problems, Not relevant Not important Significant not arising from but not hortages for areas ertain helpe

problem in

espite

long enough problem

into failing

'special

more

uppliers

Observed, bu

may not be

significan

problem in

residential ca

margin,

IVF, some

procedures 
TABLE 2. Continued

\begin{tabular}{|c|c|c|c|c|c|c|c|c|c|}
\hline $\begin{array}{l}\text { Field of } \\
\text { choice/ } \\
\text { problem type }\end{array}$ & School choice & $\begin{array}{l}\text { Nursery } \\
\text { vouchers }\end{array}$ & $\begin{array}{l}\text { Higher } \\
\text { education }\end{array}$ & $\begin{array}{l}\text { Choice } \\
\text { of GP }\end{array}$ & $\begin{array}{l}\text { Choice of } \\
\text { consultant }\end{array}$ & $\begin{array}{l}\text { Choice of } \\
\text { treatment }\end{array}$ & $\begin{array}{c}\text { Direct } \\
\text { payments }\end{array}$ & $\begin{array}{l}\text { Community } \\
\text { care }\end{array}$ & $\begin{array}{l}\text { Social rented } \\
\text { housing }\end{array}$ \\
\hline Sources & $\begin{array}{l}\text { Gewirtz et al., } \\
\text { 1995; Glatter } \\
\text { and Woods, } \\
\text { 1994; Woods } \\
\text { et al., 1998; } \\
\text { Gorard, 1997 } \\
\text { Noden, 200o; } \\
\text { 20ooa,b; Gorard } \\
\text { and Fitz, 1998a,b; } \\
\text { Goard and Taylor } \\
\text { 2002; Taylor, 2001; } \\
\text { Kendall and } \\
\text { Holloway, 2001; } \\
\text { Walford, 1996; } \\
\text { Levačić, 1994; } \\
\text { Whitty et al., 1998; } \\
\text { David et al., 1994; } \\
\text { Flatley et al., 2001; } \\
\text { Adnett and Davies, } \\
\text { 20oo; Bradley } \\
\text { et al., 1999 }\end{array}$ & $\begin{array}{l}\text { Education } \\
\text { and } \\
\text { employment } \\
\text { committee, } \\
\text { 1997; } \\
\text { Sparkes and } \\
\text { West, } 1998\end{array}$ & $\begin{array}{l}\text { Ahier, 2000; } \\
\text { Watson and } \\
\text { Bowden, 1999; } \\
\text { Dolton et al., } \\
\text { 1997; Johnes, } \\
\text { 1997; Hesketh, } \\
\text { 1999; } \\
\text { Middleton, } \\
\text { 2000; Parry, 1999; } \\
\text { Power, 2000; } \\
\text { 1999; Power, 2000 }\end{array}$ & $\begin{array}{l}\text { Charny et al., } \\
\text { 1990; Shackley } \\
\text { and Ryan, 1994; } \\
\text { Fotaki, 1998; } \\
\text { Goodwin, 1998; } \\
\text { Glennerster } \\
\text { et al., } 1994\end{array}$ & $\begin{array}{l}\text { Mahon et al., } \\
\text { 1993; Jones } \\
\text { et al., } 1993\end{array}$ & $\begin{array}{l}\text { Mahon et al., } \\
\text { 1993; Jones } \\
\text { et al., } 1993\end{array}$ & $\begin{array}{l}\text { Maglajlic et al., } \\
\text { 2ooo; Clark and } \\
\text { Spafford, 20o1; } \\
\text { Glendinning } \\
\text { et al., 20ooa,b }\end{array}$ & $\begin{array}{l}\text { Knapp et al., } \\
\text { 2001; Wistow } \\
\text { et al., 1994, 1996; } \\
\text { Wigley et al., } \\
\text { 1998; Bland, } \\
\text { 1999; Ware } \\
\text { et al., } \\
\text { forthcoming }\end{array}$ & $\begin{array}{l}\text { DETR, 2001; } \\
\text { DTLR, 2001; } \\
\text { Clapham and } \\
\text { Kintrea, 1986; } \\
\text { Pawson and } \\
\text { Kearns, } 1998\end{array}$ \\
\hline
\end{tabular}


would lead one to conclude that economy was achieved at the expense of choice.

Achieving efficiency, defined as both allocative and productive efficiency for at least constant quality, relies in part on consumers being able and willing to choose on the basis of objects of preference, that will serve to discipline producers. However, where significant proportions of consumers do not choose in this way, choice - or at least choice alone - may not bring about efficiency. For example, school choice schemes will tolerate academically under-performing schools where significant numbers of parents choose schools on non-academic criteria, and, if the prevailing policy definition of efficiency is one of unit cost for a given or increasing level of academic achievement, this is a weakness. The 'starting gun' hypothesis might be augmented with an institutionalist thesis about preference formation and change that over time the experience of a choice scheme will discipline parents to shift their preferences toward more strictly academic criteria. However, such a thesis has yet to be shown to be empirically defensible.

\section{Acceptable distributional outcomes}

The distributional outcomes of choice might be appraised on egalitarian (allocating benefits or opportunities arising from receiving the service to all clients without distinguishing by social class, ability to pay, etc.) or else on meritocratic standards (allocating benefits from receiving the service according to ability, skill, intelligence, merit, desert, etc).

While these standards quickly diverge, there is some common ground between them. Distributional outcomes of consumer choice programmes are least likely to be considered acceptable on either of these bases, where there is limited market entry, where there are problems of lock-in of consumers with underperforming suppliers, where significant numbers of conscientious choosers have segregationist preferences, where many less-conscientious choosers have inertial preferences, where voucher differentials are insufficient to compensate for differences in disadvantage or need or cost-to-service, where skilled labour has preferences for easy-to-deal-with consumers or for living in wealthy and leafy areas, where the elasticity of supply-side response is subject to ceilings in expansion, and, finally, where there is nothing much to offset producers' financial incentives to cream-skim.

However, dealing with all of these problems is costly for the public purse, especially where the only way to deal with them is to be prepared to finance continued rather than once-for-all expansion in the total size of the market.

\section{Choice, rationing and expenditure control}

Crucial to the fiscal viability of programmes of consumer choice in public services is finding a way to reconcile stimulus of choice with the requirements of rationing and expenditure control. This is true, even in fields such as community 
care where individually paid top-up fees are used and are found to be fairly widely politically acceptable. In the long term, as the experiment in the 1980s of using open-ended benefit financing to expand residential care showed, complete relaxation is not fiscally sustainable. There are basically four strategies for reconciling choice and rationing, and none is without problems:

1. control prices, as in the case of Legal Aid, or private rented housing prior to 1988 and still to some extent in the social rented housing sector;

2. limit costs eligible for subsidy, as in the case for community care and for Housing Benefit for rented housing, which is much the same as allowing 'top up' fees;

3. limit the range of products subsidised, as in the case of the NHS pharmaceutical budget; or

4. limit choice by physically limiting the numbers eligible, as US schemes for private school vouchers have done.

Each of these strategies has its risks. Price control deters entry and can stimulate exit; limiting eligible costs can do the same; limiting the range militates against responsiveness and innovation; limiting needs risks unacceptable distributional outcomes.

Of course, trying to control unit costs by bearing down on voucher size cannot easily be combined with using regulation on quality that pushes up costs, without being willing to accept significant market exit, mergers and acquisitions and slower rates of expansion, as some commentators on the New Labour educational reforms of 1997-2001 have found (Kendall and Holloway, 2001). Although there remains controversy about the effect of the new regulations in the Care Standards Act 2000 on residential care, industry representatives have argued that the anticipation alone of increased costs has resulted in higher rates of closures and lower rates of investment and entry than would otherwise have occurred, not least due to the tightening of bank credit and of the equity market for the sector. As yet it is too early for research findings to settle this, and there will always be room for disagreement about appropriate counterfactuals, but, in 2002, the government appeared implicitly to accept this argument by agreeing to relax some of the standards thought to be the most expensive for providers (Carvel, 2002).

\section{Conclusion}

Few would oppose increased choice for consumers of public services on general principle. However, designing policies to support greater individual choice presents government with both technical challenges and with conflicts of values. If they are willing to settle upon clear goals - a big 'if' in any policy process - then they must choose between the available goals, and be willing to accept that all the 
good things do not go together. The review suggests that goals of maintaining and incrementally raising satisfaction, and some improvement in efficiency can be achieved, but those of responsiveness and experiment are more difficult and more expensive to achieve. The tighter the fiscal constraints and rationing, the more difficult it is to achieve these goals.

Moreover, if policy makers are concerned about equitable distributional outcomes, and want to avoid some of the problems of adverse selection, zerosum polarisation and segregation on the basis of ascribed characteristics, then they must be prepared to spend large sums, for none of the design solutions to these problems are cheap. Adequate differential weighting of vouchers, expansion of total market size, compensation for incentives to cream-skim, and transaction cost absorption are all expensive. That there are hard choices to be made between combating social exclusion and fiscal rectitude is hardly news, but at a time when New Labour ministers are proclaiming loudly that they can achieve both, perhaps a reminder is timely.

Moreover, any initiative to extend consumer choice must take account of the lessons of the last fifteen years, and in particular of the experience of implementing the reforms of the third Thatcher administration. These represent the policy inheritance (Rose and Davies, 1994), and that inheritance, whilst by no means immutable, also defines the range of existing organisational capabilities in each of these services. New or extended programmes of consumer choice would require new capabilities among voucher-issuers and producers, even if they can be designed in ways that do not assume any change in the patterns of consumer preferences and willingness to bear the costs of conscientious choice.

Mr Blair's statement of intent in his (2001) speech may serve to raise expectations. If policy makers are willing to raise expectations of this kind, they must expect that if they cannot find affordable and feasible ways to meet them, they risk losing significant political support.

\section{Acknowledgements}

I am grateful to Keith Dowding, Julien Forder, Peter John, Julian Le Grand and Edward Peck, to two anonymous referees, and to the editors of this journal, for comments on an earlier draft of this paper and for pointers to literature. Naturally, none of them bears any responsibility for my errors nor should they necessarily be taken to agree with my conclusions.

\section{References}

Adnett, N. and Davies, P. (2000), 'Competition and curriculum diversity in local schooling markets: theory and evidence', Journal of Education Policy, 15(2): 157-67.

Ahier, J. (2000), 'Financing higher education by loans and fees: theorising and researching the private effects of a public policy', Journal of Education Policy, 15(6): 683-700.

Archer, L. and Hutchings, M. (2000), "Bettering yourself": discourses of risk, cost and benefit in ethnically diverse, young working class non-participants' constructions of higher education', British Journal of Sociology of Education, 21(4): 555-74. 
Argys, L., Rees, D. and Brewer, D. (1996), 'Detracking America's schools: equity and zero cost?', Journal of Policy Analysis and Management, 15(4): 623-64.

Ball, S. J., Davies, J., David, M. and Reay, D. (2002), "“Classification" and "judgement": social class and "cognitive structures" in choice of higher education', British Journal of Sociology of Education, 23(1): 51-72.

Bearse, P., Glomm, G. and Ravikumar, B. (2000), 'On the political economy of means-tested education vouchers', European Economic Review, 44: 904-15.

Beisäcker, A. E. (1988), 'Aging and the desire for information and input in medical decisions: patient consumerism in medical encounters', The Gerontologist, 28(3): 330-5.

Blair, T. (2001), Prime Minister's speech on public service reform, available at http://www. number10.gov.uk/news.asp?NewsId $=2765 \&$ SectionId $=32$.

Bland, R. (1999), 'Independence, privacy and risk: two contrasting approaches to residential care for older people', Ageing and Society, 19(5): 539-60.

Bowles, S. and Gintis, H. (1996), 'Efficient redistribution: new rules for markets, states and communities', Politics and Society, 24(4): 307-42.

Bradley, S., Johnes, G. and Millington, J. (1999), 'School choice, competition and the efficiency of secondary schools in England', Working paper, EC3/99, Centre for Research in the Economics of Education Discussion Paper, Department of Economics, Lancaster University, Lancaster.

Brighouse, H. (2000), School Choice and Social Justice, Oxford: Oxford University Press.

Carvel, J. (2002), 'Milburn retreats on care home standards', The Guardian, 20 August, p. 5, available at http://politics.guardian.co.uk/publicservices/story/o,11032,777610,0o.html.

Charny, M., Klein, R. E., Lewis, P. A. and Tipping, G. K. (1990), 'Britain's new market model of general practice: do consumers know enough to make it work?', Health Policy, 14(4): $243-52$.

Chubb, J. and Moe, T. (1990), Politics, Markets and America's Schools, Washington, DC: Brookings Institute.

Clapham, D. and Kintrea, K. (1986), 'Rationing, choice and constraint: the allocation of public housing in Glasgow', Journal of Social Policy, 15(1): 51-67.

Clark, H. and Spafford, J. (2001), Piloting Choice and Control for Older People: An Evaluation, York: Policy Press and Joseph Rowntree Foundation.

Darkins, A. (1996), 'Shared decision making in health care systems', unpublished paper, cited in O. Morgan (1998), Who Cares? The Great British Health Debate, Oxford: Radcliffe Press, p. 76, n.15.

David, M., West, A. and Ribbens, J. (1994), Mother's Intuition? Choosing Secondary Schools, London: Falmer Press.

Davis, A., Ellis, K. and Rummery, K. (1997), Access to Assessment: Perspectives of Practitioners, Disabled People and Carers, Bristol: Policy Press.

Department of the Environment, Transport and the Regions (2000), 'Quality and choice: a decent home for all', The Housing Green Paper, Department of the Environment, Transport and the Regions, London.

Department of Health (1999), 'National service framework for mental health', Department of Health, London.

Department of Health (2002), 'Expanded services and increased choices for older people: investment and reform for older people's social services', Department of Health, London, July, available at http://tap.ukwebhost.(eds.)com/doh/Intpress.nsf/page/2002-0324? Open Document.

Department for Transport, Local Government and the Regions (2001), 'Choice based lettings', Newsletter issue No 1, Department for Transport, Local Government and the Regions, London, available at http://www.housing.dtlr.gov.uk/information/cbaselet/newsletter. htm.

Dolton, P. J., Greenaway, D. and Vignoles, A. (1997), "Whither higher education?" an economic perspective for the Dearing Committee of Inquiry', The Economic Journal, 107: 710-26. 
Doty, P., Kasper, J. and Litvak, S. (1996), 'Consumer-directed models of personal care: lessons from Medicaid', Milbank Quarterly, 74(3): 377-409.

Dowding, K. (1992), 'Choice: its increase and its value', British Journal of Political Science, 22: $301-14$.

Education and Employment Committee (1997), The operation of the nursery education voucher scheme', 12 March, 3rd report, session 1996-97, House of Commons papers, vol. 25.

Fiske, E. B. and Ladd, H. F. (200o), When Schools Compete: A Cautionary Tale, Washington, DC: Brookings Institution.

Flatley, J., Connolly, H., Higgins, V., Williams, J., Coldron, J., Stephenson, K., Logie, A. and Smith, N. (2001), 'Parents' experiences of the process of choosing a secondary school', Research report 278, Department for Education and Skills, London.

Fotaki, M. (1998), 'The impact of market oriented reforms on patient choice and information: a case study of cataract surgery in outer London and Stockholm', Social Science and Medicine, 48(10): 1415-32.

Gewirtz, S., Ball, S. J. and Bowe, R. (1995), Markets, Choice and Equity in Education, Buckingham: Open University Press.

Gibson, A. and Asthana, S. (1999), 'What's in a number?', Research Papers in Education, 15: 133-54.

Glatter, R. and Woods, P. (1994), 'The impact of competition and choice on parents and schools', in W. Bartlett, C. Propper, D. Wilson and J. Le Grand (eds.), Quasi-Markets in the Welfare State, Bristol: SAUS Press, pp. 56-77.

Glendinning, C., Halliwell, S., Jacobs, S., Rummery, K. and Tyrer, J. (200oa), 'Bridging the gap: using Direct Payments to purchase integrated care', Health and Social Care in the Community, 8(3): 192-200.

Glendinning, C., Halliwell, S., Jacobs, S., Rummery, K. and Tyrer, J. (200ob), 'New kinds of care, new kinds of relationships: how purchasing services affects relationships in giving and receiving personal assistance', Health and Social Care in the Community, 8(3): 201-11.

Glennerster, H. (1992), Paying for Welfare: The 199os, Hemel Hempstead: Harvester Wheatsheaf.

Glennerster, H. (1993), 'The economics of education: changing fortunes', in N. Barr and D. Whynes (eds.), Current Issues in the Economics of Welfare, Basingstoke: Macmillan, pp. 176-99.

Glennerster, H. (1998), 'Education: reaping the harvest?', in H. Glennerster and J. Hills (eds.), The State of Welfare: The Economics of Social Spending, and edn, Oxford: Oxford University Press, pp. 27-74.

Glennerster, H., Matsaganis, M. and Owens, P. with Hancock, S. (1994), Implementing GP Fundholding, Buckingham: Open University Press.

Goodwin, N. (1998), 'GP fundholding', in J. Le Grand, N. Mays and J.-A. Mulligan (eds.), Learning from the NHS Internal Market: A Review of the Evidence, London: King's Fund, pp. $43-68$.

Gorard, S. (1997), School Choice in an Established Market, Aldershot: Ashgate.

Gorard, S. (2000a), 'One of us cannot be wrong: the paradox of achievement gaps', British Journal of Sociology of Education, 21(3): 391-400.

Gorard, S. (200ob), 'Questioning the crisis account: a review of evidence for increasing polarisation in schools', Educational Research, 42(3): 309-21.

Gorard, S. and Fitz, J. (1998a), 'The more things change... the missing impact of marketisation?', British Journal of Sociology of Education, 19(3): 365-76.

Gorard, S. and Fitz, J. (1998b), "Under starters" orders: the established market, the Cardiff study and the Smithfield project', International Studies in Sociology of Education, 8: 299-314.

Gorard, S. and Taylor, C. (2002), 'Market forces and standards in education: a preliminary consideration', British Journal of Sociology of Education, 23(1): 6-18.

Gordon, L. (1996), 'School choice and the quasi-market in New Zealand', in G. Walford (ed.), School Choice and the Quasi-Market Oxford, Studies in Comparative Education, vol. 6 (1), Wallingford: Triangle Books, pp. 129-42. 
Hardy, B., Young, R. and Wistow, G. (1999a), 'Dimensions of choice in the assessment and care management process: the views of older people, carers and care managers', Health and Social Care in the Community, 7(6): 483-91.

Hardy, B., Forder, J., Kendall, J., Knapp, M. R. J. and Wistow, G. (1999b), 'Provider relationships with local authority purchasers', Nuffield Institute for Health, University of Leeds, Leeds.

Hasler, F., Campbell, J. and Zarb, G. (1999), 'Direct routes to independence: a guide to local authority implementation and management of direct payments', National Centre for Independent Living and Policy Studies Institute, London.

Hassel, B. C. (1999), The Charter School Challenge: Avoiding the Pitfalls, Fulfilling the Promise, Washington, DC: Brookings Institution.

Henig, J. R. (1994), Rethinking School Choice: Limits of the Market Metaphor, Princeton, NJ: Princeton University Press.

Hesketh, A. J. (1999), 'Towards an economic sociology of the student financial experience of higher education', Journal of Educational Policy, 14(4): 385-410.

Horvath, A. O. and Symonds, B. D. (1991), 'Relation between working alliance and outcome in psychotherapy: a meta-analysis', Journal of Consulting and Clinical Psychology, 38: 139-49.

Hoxby, C. (2001), 'School choice and school productivity, or could school choice be a tide that lifts all boats?', paper presented at the National Bureau for Economic Research conference on The economics of school choice, Islamorada, Florida, 22-24 February.

Inglehart, J. K. (1995), 'Medicaid and managed care', New England Journal of Medicine, 332: 1727-31.

Johnes, G. (1997), 'Cost and industrial structure in contemporary British higher education', The Economic Journal, 107: 727-37.

Jones, D., Lester, C. and West, R. (1993), 'Monitoring changes in health services for older people', in R. Robinson and J. Le Grand (eds.), Evaluating the NHS Reforms, Buckinghamshire Hermitage Policy Journals, pp. 130-54.

Kendall, I. and Holloway, D. (2001), 'Education policy', in S. P. Savage and R. Atkinson (eds.), Public Policy under Blair, Basingstoke: Palgrave, pp. 154-73.

Klein, R. E. (1995), The New Politics of the NHS, 3rd edn, Harlow: Longman.

Klein, R. E. and Millar, J. (1995), 'Do-it-yourself social policy: searching for a new paradigm?', Social Policy and Administration, 29(4): 303-16.

Knapp, M., Hardy, B. and Forder, J. (2001), 'Commissioning for quality: ten years of social care markets in England', Journal of Social Policy, 30(2): 283-306.

Ladd, H. F. and Fiske, E. B. (2001), 'The uneven playing field of school choice: evidence from New Zealand', Journal of Policy Analysis and Management, 20(1): 43-64.

Le Grand, J. (1989), 'Markets, welfare and equality', in J. Le Grand and S. Estrin (eds.), Market Socialism, Oxford: Oxford University Press.

Le Grand, J., Mays, N. and Mulligan, J.-A. (eds.) (1998), Learning from the NHS Internal Market: A Review of the Evidence, London: King's Fund.

Levačić, R. (1994), 'Evaluating the performance of quasi-markets in education', in W. Bartlett, C. Propper, D. Wilson and J. Le Grand (eds.), Quasi-Markets in the Welfare State, Bristol: SAUS Press, pp. 35-55.

Maglajlic, R., Brandon, D. and Given, D. (2000), 'Making Direct Payments a choice: a report on research findings', Disability and Society, 15(1): 99-113.

Mahon, A., Wilkin, A. and Whitehouse, C. (1993), 'Choice of hospital for elective surgery referral: GPs' and patients' views', in R. Robinson and J. Le Grand (eds.), Evaluating the NHS Reforms, Buckinghamshire: Hermitage Policy Journals, pp. 108-29.

Matsaganis, M. and Glennerster, H. (1994), 'Cream skimming and fundholding', in W. Bartlett, C. Propper, D. Wilson and J. Le Grand (eds.), Quasi-Markets in the Welfare State, Bristol: SAUS Press, pp. 245-67.

Merrett, S. (1979), State Housing in Britain, London: Routledge \& Kegan Paul.

Middleton, C. (2000), 'Models of state and market in the 'modernisation' of higher education', British Journal of Sociology of Education, 21(4): 537-54. 
Milburn, A. (2002), 'Redefining the National Health Service', Speech by Rt Hon Alan Milburn MP, Secretary of State for Health, to the New Health Network, London, 15 January 2002.

Moe, T. (ed.) (1995), Private Vouchers, Stanford, CA: Hoover Institution Press.

Morgan, O. (1998), Who Cares? The Great British Health Debate, Oxford: Radcliffe Press.

Mulligan, J.-A. (1998), 'Health authority purchasing', in J. Le Grand, N. Mays, and J.-A. Mulligan (eds.), Learning from the NHS Internal Market: A Review of the Evidence, London: King's Fund, pp. 20-42.

Noden, P. (2000), 'Rediscovering the impact of marketisation: dimensions of social segregation in England's secondary schools, 1994-99', British Journal of Sociology of Education, 21(3): 371-90.

Office of Public Services Reform (2002), 'Reforming our public services: principles into practice', Office of Public Services Reform, Cabinet Office, London.

Parry, G. (1999), 'Education research and policy making in higher education: the case of Dearing', Journal of Education Policy, 14(3): 225-41.

Pawson, H. and Kearns, A. (1998), 'Difficult to let housing association stock in England: property, management and context', Housing Studies, 13(3): 391-414.

Power, S. (2000), 'Educational pathways into the middle class(es)', British Journal of Sociology of Education, 21(2): 133-46.

Redmayne, S. (1995), 'Reshaping the NHS: strategies, priorities and resource allocation', NAHAT Research Paper 13, National Association of Health Authorities and Trusts, Birmingham.

Robinson, R. and Le Grand, J. (eds.) (1993), Evaluating the NHS Reforms, Buckinghamshire: Hermitage Policy Journals.

Rose, R. and Davies, P. (1994), Inheritance in Public Policy: Change without Choice in Britain, New Haven: Yale University Press.

Roth, A. and Fonay, P. (1996), What Works for Whom?, New York: Guilford Press.

Safran J. D. and Muran J. C. (1996), 'The resolution of ruptures in the therapeutic alliance', Journal of Consulting and Clinical Psychology, 64: 447-58.

Secretary of State for Health (2002), 'Delivering the NHS plan: next steps on investment, next steps on reform', Cm 5503, Stationery Office, London.

Segal, L. (1998), 'The important of patient empowerment in health system reform', Health Policy, 44(1): 31-44.

Shackley, P. and Ryan, M. (1994), 'What is the role of the consumer in health care?', Journal of Social Policy, 23(4): 517-41.

Social Services Inspectorate (2002), 'Modern Social Services: A Commitment to Reform', London.

Sparkes, J. and West, A. (1998), 'An evaluation of the English Nursery Voucher Scheme, 19961997', Education Economics, 6(2): 171-84.

Syme, S. L. (1996), 'To prevent disease: the need for a new approach', in D. Blane, E. Brunner and D. Wilkinson (1996), Health and Social Organisation: Towards a Health Policy for the Twenty First Century, London: Routledge, pp. 21-31.

Taylor, C. (2001), 'Hierarchies and "local" markets: the geography of the "lived" marketplace in secondary education provision', Journal of Education Policy, 16(3): $197-214$

Tudor Hart, J. (1971), 'The inverse care law', The Lancet, 1: 405-12.

Walford, G. (1996), 'School choice and the quasi-market in England and Wales', in G. Walford (ed.), School Choice and the Quasi-Market, Oxford Studies in Comparative Education, 6(1), Wallingdon: Triangle Books, pp. 49-62.

Ware, T., Matosevic, T., Hardy, B., Knapp, M., Kendall, J. and Forder, J. (forthcoming), 'Commissioning services for older people: the view from care managers, users and carers', Ageing and Society.

Waslander, S. and Thrupp, M. (1995), 'Choice, competition and segregation: an empirical analysis of a New Zealand secondary school market', Journal of Education Policy, 10(1): $1-26$. 
Watson, D. and Bowden, R. (1999), 'Why did they do it? The Conservatives and mass higher education, 1979-1997', Journal of Education Policy, 14(3): 243-56.

West, A., Noden, P., Edge, A., David, M. and Davies, J. (1998), 'Choices and expectations at primary and secondary stages in the state and private sectors', Educational Studies, 24(1): 45-60.

Whitty, G., Power, S. and Halpin, D. (1998), Devolution and Choice in Education: The State, the School and the Market, Buckingham: Open University.

Wigley, V., Fisk, M., Gisby, B. and Preston-Shoot, M. (1998), 'Older people in care homes: consumer perspectives', Liverpool John Moores University, Liverpool.

Wilton, P. and Smith, R. D. (1998), 'Primary care reform: a three country comparison of "budget holding"', Health Policy, 44(2): 149-66.

Wistow, G., Knapp, M., Hardy, B. and Allen, C. (1994), Social Care in a Mixed Economy, Buckingham: Open University Press.

Wistow, G., Knapp, M., Hardy, B., Forder, J., Kendall, J. and Manning, R. (1996), Social Care Markets: Progress and Prospects, Buckingham: Open University Press.

Woods, P. A., Bagley, C. and Glatter, R. (1998), School Choice and Competition: Markets in the Public Interest, London: Routledge.

Zimmer, R. W. and Toma, E. F. (2000), 'Peer effects in private and public schools across countries', Journal of Policy Analysis and Management, 19(1): 75-92.

6, P. (1998), 'Ownership and the new politics of the public interest services', Political Quarterly, 69(4): 404-14. 